\title{
Long-term analysis of bilateral versus unilateral neck dissection in the treatment of early-stage supraglottic laryngeal cancer
}

\author{
Supraglottik larenks kanser tedavisinde iki tarafl ve tek tarafl boyun diseksiyonu uzun \\ dönem sonuçlarının karşılaştırılması
}

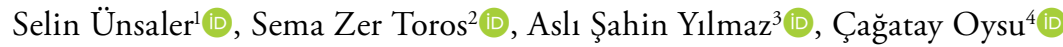 \\ ${ }^{1}$ Department of Otolaryngology, Koç University School of Medicine, Istanbul, Turkey \\ ${ }^{2}$ Department of Otolaryngology, University of Health Sciences, Haydarpaşa Numune Training and Research Hospital, Istanbul, Turkey \\ ${ }^{3}$ Department of Otolaryngology, University of Health Sciences, Ümraniye Training and Research Hospital, Istanbul, Turkey \\ ${ }^{4}$ Department of Otolaryngology, Marmara University School of Medicine, Istanbul, Turkey
}

\begin{abstract}
Objectives: This study aimed to investigate the effect of routine bilateral neck dissection on the survival outcomes of supraglottic laryngeal cancer patients with lateralized tumors and clinically negative necks.

Patients and Methods: The data of 234 patients surgically treated for supraglottic squamous cell carcinoma between January 2000 and September 2014 were retrospectively collected. Patients treated previously for head and neck cancer, patients who could not be contacted, and those with missing data were excluded. Of the remaining 187 patients, 124 patients with early-stage primaries (T1-T2) (116 males, 8 females; mean age: $55.5 \pm 9.5$ years; range, 33 to 82 years) were included. Age and sex of the patients, site of the primary tumor, TNM stage, type of the neck dissection, length of follow-up, and survival rates were evaluated. The tumors were classified into three groups according to their relationship with the median line of the larynx, and the neck dissections were recorded as unilateral or bilateral. Recurrences and survival outcomes were evaluated.

Results: There was no statistically significant difference in the recurrences according to tumor site groups $(\mathrm{p}=0.39)$. Similarly, there was no statistically significant difference in 10 -year overall survival rates in patient groups according to the tumor site $(p=0.072)$. We found no statistically significant difference in 10 -year overall survival rates between the patients who underwent unilateral and bilateral neck dissection $(\mathrm{p}=0.580)$.

Conclusion: Long-term survival analysis of 124 patients with supraglottic carcinoma did not show a survival benefit of elective contralateral neck dissection in lateralized supraglottic cancer with contralateral clinically negative neck.

Keywords: Laryngeal cancer, neck dissection, supraglottis.
\end{abstract}

$\ddot{O} Z$

Amaç: Bu çalışmada lateralize tümörlü supraglottik larenks kanseri hastalarında, klinik olarak negatif boyun varlığında rutin iki taraflı boyun diseksiyonunun sağkalım sonuçlarına etkisi araştırıldı.

Hastalar ve Yöntemler: Skuamöz hücreli supraglottik larenks karsinomu nedeniyle Ocak 2000 - Eylül 2014 tarihleri arasında cerrahi olarak tedavi edilen 234 hastanın verileri retrospektif olarak toplandı. Daha önce baş ve boyun kanseri nedeniyle tedavi gören hastalar ile ulaşılamayan veya verileri eksik olan hastalar çalışma dışı bırakıldı. Geriye kalan 187 hastadan, erken evreli primerleri (T1-T2) olan 124 hasta (116 erkek, 8 kadın; ort. yaş: $55.5 \pm 9.5$ yıl; dağılım, 33-82 yıl) çalışmaya dahil edildi. Hastaların yaş ve cinsiyeti, primer tümörün yerleşim yeri, TNM evresi, boyun diseksiyonu tipi, takip süresi ve sağkalım oranları değerlendirildi. Tümörler larenks orta hat ile ilişkilerine göre üç gruba ayrıldı, boyun diseksiyonları da tek taraflı veya iki taraflı olarak kaydedildi. Rekürrensler ve sağkalım sonuçları değerlendirildi.

Bulgular: Tümör yerleşim yerine göre oluşturulan gruplarda, rekürrens oranları arasında istatistiksel olarak anlamlı bir fark bulunmadı $(p=0.39)$. Benzer şekilde, tümör yerleşim yerine göre 10 yıllık sağkalım oranlarında da istatistiksel olarak anlamlı bir fark yoktu $(\mathrm{p}=0.072)$. Tek tarafl $l_{1}$ ve iki taraflı boyun diseksiyonu yapılan hastalar arasında da 10 yıllık genel sağkalım oranları açısından istatistiksel olarak anlamlı bir fark saptanmadı $(\mathrm{p}=0.580)$.

Sonuç: Supraglottik karsinomlu 124 hastanın uzun dönem sağkalım analizine göre, klinik olarak karşı taraf boynu negatif lateralize supraglottik kanserde, elektif karşı taraf boyun diseksiyonunun sağkalım üzerine avantajı gözlenmedi.

Anahtar sözcükler: Larenks kanseri, boyun diseksiyonu, supraglottis. 
In head and neck cancers, the most important parameter in terms of survival is the stage of metastatic disease in the neck. ${ }^{[1]}$ Supraglottic carcinoma of the larynx has a strong predilection for cervical metastases since it has rich lymphatic drainage compared to other laryngeal sites ${ }^{[2,3]}$ Nodal status is the main prognostic factor in the curability and survival of those patients. ${ }^{[4-7]}$ Since the incidence of occult neck metastasis has been reported to reach up to $30 \%$, the elective treatment of the N0 neck is routinely performed. ${ }^{[8]}$ The primary therapy chosen for the treatment of the primary lesion is generally the accepted treatment also for the N0 neck, ${ }^{[4]}$ and thus selective neck dissection is performed correspondingly in case of surgical treatment of the primary lesion.

Supraglottic cancers have a higher risk of contralateral or bilateral neck metastases. However, it is reported that lateralized primary tumors are rarely metastatic to the contralateral neck at the time of diagnosis. ${ }^{\left[{ }^{[9}\right.}$ Longer operative time, increased postoperative complications and morbidity are the potential risks of bilateral neck dissections. ${ }^{[10]}$ When to perform bilateral neck dissection in a lateralized primary with a clinically negative neck is still a matter of debate.

The current trend in the treatment of laryngeal cancer shows that radiotherapy or chemoradiotherapy protocols are frequently preferred. If surgery is chosen as the primary treatment modality, it should be targeted to reduce morbidity and improve the long-term quality of life without impairing the patient's life expectancy. Consequently, surgery of the contralateral neck in lateralized laryngeal cancer is a controversial issue regarding the patient's perioperative and postoperative morbidity. This study aimed to investigate whether routine bilateral neck dissection in clinically negative necks improves treatment outcomes of the supraglottic cancer patients with lateralized tumors by retrospectively analyzing the clinical, pathological, and follow-up data.

\section{PATIENTS AND METHODS}

In this study, retrospective data of 234 patients surgically treated for supraglottic squamous cell carcinoma by supraglottic laryngectomy and its modifications were collected from January 2000 and September 2014. The data was collected from three different tertiary referral centers. Patients treated previously for head and neck cancer with surgery or radiotherapy and patients who could not be contacted or those with missing data were excluded from the study. Of the remaining 187 patients, 124 patients (116 males, 8 females; mean age: $55.5 \pm 9.5$ years; range, 33 to 82 years) with early-stage primaries [T-stage 1 and 2 according to the $8^{\text {th }}$ edition of American Joint Committee on Cancer (AJCC) staging manual] were included in the study; T3 and T4 tumors and N-positive patients $(n=53)$ were excluded. Age and sex of the patients, site of the primary tumor, TNM stage, type of the neck dissection, length of follow-up after surgery, and the survival rates were evaluated.

The tumors were classified according to their relationship with the median line of the larynx as following: well-lateralized tumors not involving the midline (Group 1), lateralized tumors extending up to the midline (Group 2), and centrally located tumors involving both sides equally (Group 3).

Inclusion criteria to define the N0 neck in laryngeal cancer patients were based upon characteristics of detectable lymph nodes in contrast-enhanced computed tomography or magnetic resonance imaging. The neck dissections were performed either as unilateral or

\section{Table 1}

Tumor site, neck dissection, and evaluation of recurrence according to neck dissection and tumor site ( $\mathrm{n}=28)$

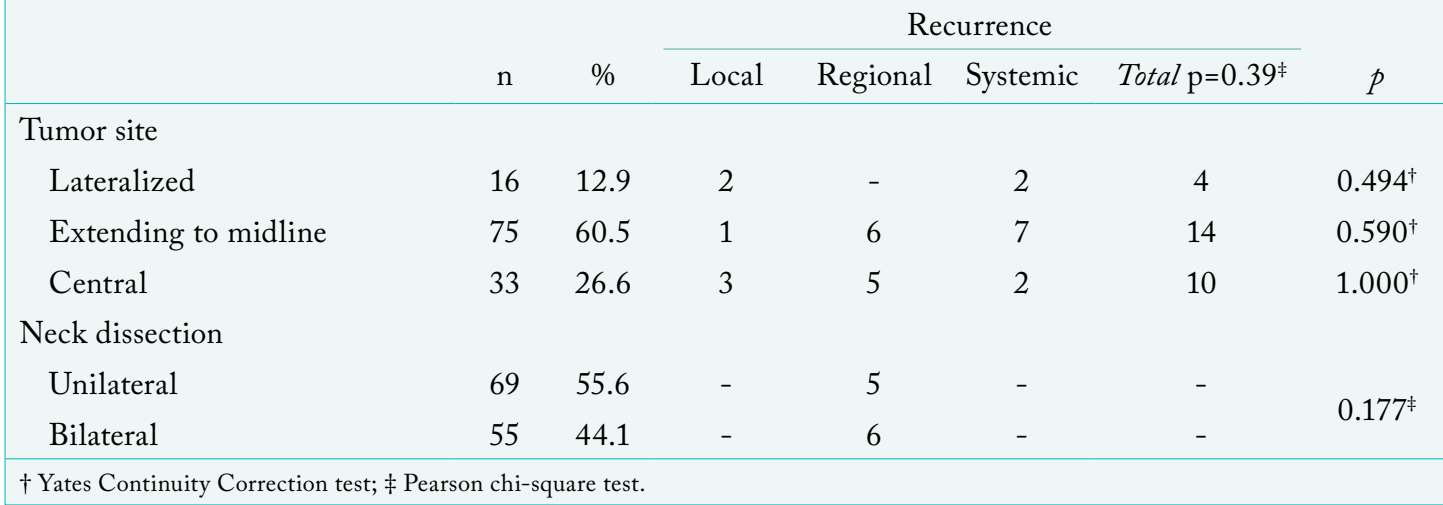




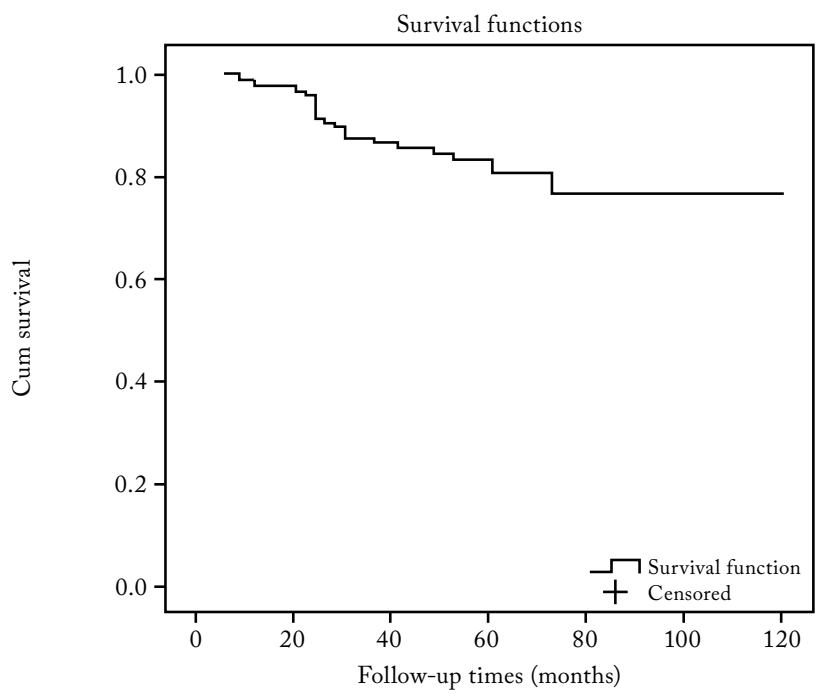

Figure 1. Overall survival curve.

bilateral considering the laterality of the primary tumor, meaning that unilateral neck dissection was chosen for well-lateralized tumors, and bilateral neck dissection was performed for midline tumors and those crossing the midline.

\section{Statistical analysis}

Statistical analyses was performed using the IBM SPSS version 21.0 software (IBM Corp.; Armonk, NY, USA). In addition to standard descriptive statistical calculations (median, standard deviation, frequency, and ratio), One-way analysis of variance (ANOVA), Pearson chi-square test, Yates' continuity correction, and Fisher's exact test were used in the assessment of parameters. The overall survival and disease-specific survival rates were calculated with the Kaplan-Meier method and log-rank test. The statistical significance level was determined as $\mathrm{p}<0.05$.

\section{RESULTS}

The median follow-up time was $68.6 \pm 42.2$ (range, 60 to 120$)$ months.

\section{Evaluation of tumor site}

Group 1 consisted of 16 (12.9\%) patients with welllateralized tumors, Group 2 consisted of 75 (60.5\%) patients with lateralized tumors extending up to the midline, and Group 3 consisted of 33 (26.6\%) patients with centrally located tumors (Table 1 ).

\section{TNM staging}

The tumors were classified as $\mathrm{T} 1$ in 16 (12.9\%) patients and T2 in 108 (87.1\%) patients. All patients were staged N0 preoperatively. Final pathological examination demonstrated N0 in 101 (81.5\%) patients and N1 in 23 (18.5\%) patients. Thus, the neck status of 23 patients was upstaged in the postoperative pathological staging, and the unilateral metastatic lymph node was located ipsilaterally in all patients. No contralateral metastasis was observed.

\section{Neck dissection}

Bilateral neck dissections were performed in 55 (44.4\%) patients, and unilateral neck dissection was performed in $69(55.6 \%)$ patients (Table 1). All patients in Group 3 and 22 patients in Group 2 with primary tumor stage T2 underwent bilateral neck dissection.

\section{Recurrences}

Recurrences were classified as local, regional, and systemic, which was observed in $28(22.6 \%)$ patients, and the details were given in Table 1 . The median time to relapse was $43.9 \pm 49.1$ months. There was no statistically significant difference in recurrences according to the tumor site and the type of neck dissection ( $p>0.05)$.

\begin{tabular}{|c|c|c|c|c|c|c|}
\hline \multicolumn{7}{|c|}{$\begin{array}{r}\text { Table } 2 \\
\text { sis according to neck dis }\end{array}$} \\
\hline & \multicolumn{2}{|c|}{ Overall survival } & \multicolumn{2}{|c|}{ Disease specific survival } & \multirow{2}{*}{$\begin{array}{c}\text { Disease specific mean } \\
\text { survival time } \\
\text { Mean } \pm \text { SD }\end{array}$} & \multirow{2}{*}{$\begin{array}{c}\text { 95\% CI } \\
\text { Lower-Upper }\end{array}$} \\
\hline & $\mathrm{n}$ & $\%$ & $\mathrm{n}$ & $\%$ & & \\
\hline \multicolumn{7}{|l|}{ Neck dissection } \\
\hline Unilateral $(n=69)$ & 55 & 79.7 & 60 & 86.9 & $102.9 \pm 3.5$ & $96.155-109.702$ \\
\hline Bilateral $(n=55)$ & 42 & 76.4 & 46 & 83.6 & $99.5 \pm 5.2$ & 89.285-109.795 \\
\hline \multicolumn{7}{|l|}{ Tumor site } \\
\hline Lateralized $(n=16)$ & 14 & 87.5 & 14 & 87.5 & $99.5 \pm 5.1$ & 89.589-109.405 \\
\hline Extending to midline $(n=75)$ & 58 & 77.3 & 65 & 86.7 & $109.1 \pm 3.6$ & $108.074-116.203$ \\
\hline Central $(n=33)$ & 25 & 75.8 & 27 & 81.8 & $92.5 \pm 6.9$ & $78.862-106.088$ \\
\hline
\end{tabular}




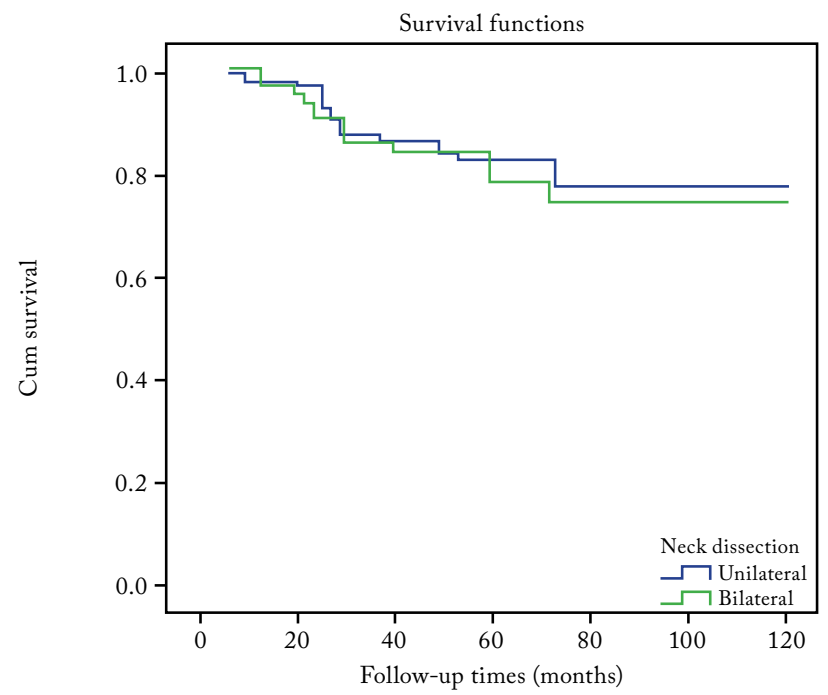

Figure 2. Survival curves according to the neck dissection performed.

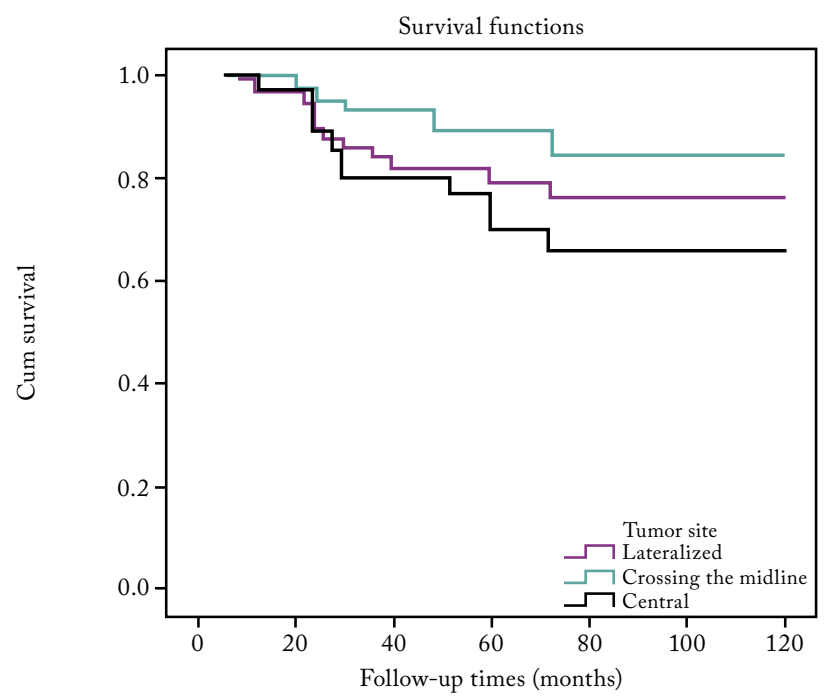

Figure 3. Survival curves according to the tumor site.

\section{Survival analysis}

Of all 124 patients, 97 (78.2\%) survived, and 27 died. Of the 27 patients, 18 died due to recurrence or metastasis of the laryngeal cancer, and the diseasespecific survival rate was $87.1 \%$. The mean survival time was $101.8 \pm 2.9$ months (Figure 1). Among the patients $(\mathrm{n}=69)$ who underwent unilateral neck dissection, $55(79.7 \%)$ patients survived. Of the 55 patients who underwent the bilateral neck dissection, 42 (76.4\%) survived. There was no statistically significant difference in 10-year overall survival rates between the patients who underwent unilateral or bilateral neck dissection by the log-rank test $(p=0.580 ; p>0.05)$

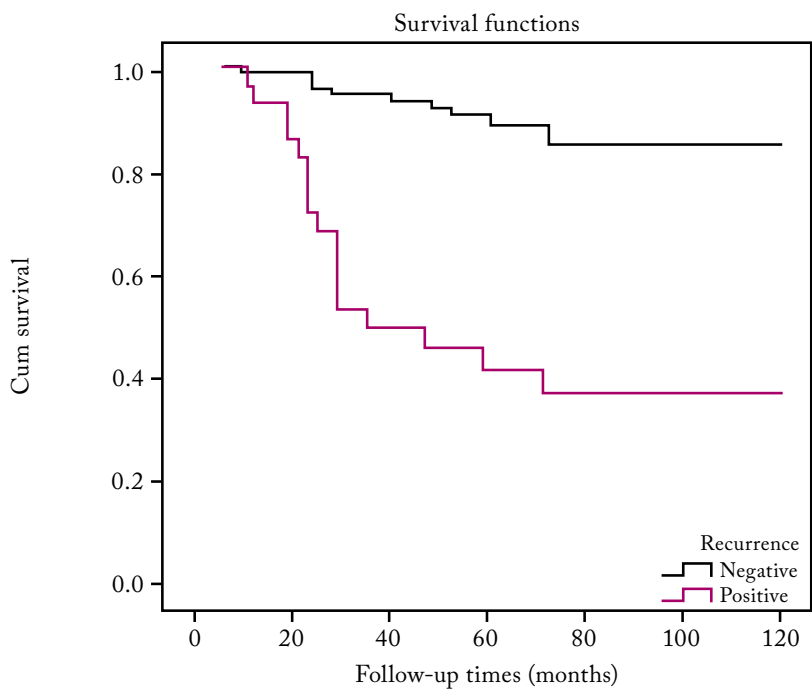

Figure 4. Survival curves according to the status of recurrence.

(Table 2, Figure 2). There was no statistically significant difference in 10-year overall survival rates between patient groups according to tumor site $(\mathrm{p}=0.072 ; \mathrm{p}>0.05)$ (Table 2, Figure 3). The overall survival rate was lower in patients with recurrences $(\mathrm{p}<0.01)$ (Figure 4).

\section{DISCUSSION}

The presence of neck metastases invariably affects the survival of patients with laryngeal cancer ${ }^{[8]}$ Despite advances in diagnostic tools, occult metastases may not be identified accurately. Carcinomas originating from the supraglottic region have a strong predilection for neck metastases due to the rich lymphatic network and the increased likelihood of early occult lymphatic metastases. Therefore, in most centers, routine elective neck dissection of both sides of the neck is performed in clinically and radiologically NO patients with supraglottic carcinoma. ${ }^{[11]}$ Simultaneous neck dissection of the opposite side may have some side effects, such as prolonged operation time, risk of ansa cervicalis injury in both sides, and increased laryngeal edema, which delays decannulation and swallowing rehabilitation. Thus, a contralateral neck dissection without oncological benefits will cause a delay in the patient's postoperative rehabilitation process.

It is unclear how and when to treat the clinically negative neck. The lymphatic drainage pattern is imperative in estimating the pattern of metastases. There is no contralateral lymphatic flow in the neck. Additionally, there are numerous valves, which favors descending unidirectional flow within the lymphatic vessels. Therefore, lateralized supraglottic carcinoma 
follows the ipsilateral lymphatic vessels draining to levels II and III. ${ }^{[12]}$ The pattern of lymphatic distribution can change after surgical procedures for negative pathologies. ${ }^{[13]}$ Elective neck dissection removes a barrier to the spread of disease and may disturb the mechanisms of recognition and elimination of neoplastic emboli.

When ipsilateral neck metastases are clinically evident, the contralateral neck is treated either by neck dissection or postoperative irradiation. ${ }^{[13]}$ Contralateral metastases in lateralized lesions are infrequent in the absence of ipsilateral metastases. ${ }^{[14]}$ Two authors reported a prevalence of less than $10 \%$ of contralateral metastases in lateral supraglottic neoplasms. ${ }^{[15,16]} \mathrm{A}$ higher prevalence was observed only when central and lateral neoplasms were concurrent. ${ }^{[3]}$ In our study, $18 \%$ of the patients were upstaged from $\mathrm{N} 0$ to $\mathrm{N} 1$; however, the unilateral metastatic lymph node was located ipsilaterally in all patients.

Unnecessary neck dissections may be correlated with higher morbidity due to the increased operation time, longer hospital stay, and delayed wound healing. ${ }^{[17]}$ Routine use of bilateral neck dissection in clinically and radiologically $\mathrm{N} 0$ patients results in more than $50 \%$ negative neck specimens. ${ }^{[18]}$ Bilateral elective neck dissection is advised in centrally located lesions since centrally located supraglottic tumors have a high risk of bilateral metastases. ${ }^{[6,14]}$

Gallo et al. ${ }^{[9]}$ reported that bilateral neck involvement is more frequent in the group of patients with midline supraglottic tumors than those extending up to the midline, whereas well-lateralized tumors has the lowest metastasis rate. This finding is consistent with our study. Similarly, our results do not support contralateral elective neck dissection for the clinically negative neck since unnecessary bilateral procedures do not contribute to survival. Bilateral neck dissections may be reserved for the cases with a clinically positive ipsilateral neck. However, it should be noted that the cohort of this study comprised exclusively early T-stage tumors (T1, T2); T3-T4 tumors were excluded from this study.

In conclusion, long-term survival of 124 patients with early-stage supraglottic carcinoma did not show a statistical benefit of elective contralateral neck dissection in patients with lateralized supraglottic cancer and a contralateral clinically negative neck. In lateralized supraglottic tumors, bilateral neck dissections may be reserved for cases with a clinically positive ipsilateral neck to lessen the surgical complications and morbidity.

\section{Declaration of conflicting interests}

The authors declared no conflicts of interest with respect to the authorship and/or publication of this article.

\section{Funding}

The authors received no financial support for the research and/or authorship of this article.

\section{REFERENCES}

1. Kowalski LP, Medina JE. Nodal metastases: Predictive factors. Otolaryngol Clin North Am 1998;31:621-37.

2. Yüce I, Cağli S, Bayram A, Güney E. Occult metastases from T1-T2 supraglottic carcinoma: Role of primary tumor localization. Eur Arch Otorhinolaryngol 2009;266:1301-4.

3. Redaelli de Zinis LO, Nicolai P, Tomenzoli D, Ghizzardi D, Trimarchi M, Cappiello J, et al. The distribution of lymph node metastases in supraglottic squamous cell carcinoma: T herapeutic implications. Head Neck 2002;24:913-20.

4. Rodrigo JP, Cabanillas R, Franco V, Suárez C. Efficacy of routine bilateral neck dissection in the management of the N0 neck in T1-T2 unilateral supraglottic cancer. Head Neck 2006;28:534-9.

5. Chiu RJ, Myers EN, Johnson JT. Efficacy of routine bilateral neck dissection in the management of supraglottic cancer. Otolaryngol Head Neck Surg 2004;131:485-8.

6. Amar A, Chedid HM, Franzi SA, Rapoport A. Neck dissection in squamous cell carcinoma of the larynx: Indication of elective contralateral neck dissection. Braz J Otorhinolaryngol 2012;78:7-10.

7. Lutz CK, Johnson JT, Wagner RL, Myers EN. Supraglottic carcinoma: Patterns of recurrence. Ann Otol Rhinol Laryngol 1990;99:12-7.

8. Cağli S, Yüce I, Yiğitbaşi OG, Güney E. Is routine bilateral neck dissection absolutely necessary in the management of N0 neck in patients with supraglottic carcinoma? Eur Arch Otorhinolaryngol 2007;264:1453-7.

9. Gallo O, Fini-Storchi I, Napolitano L. Treatment of the contralateral negative neck in supraglottic cancer patients with unilateral node metastases (N1-3). Head Neck 2000;22:386-92.

10. Bohannon IA, Desmond RA, Clemons L, Magnuson JS, Carroll WR, Rosenthal EL. Management of the N0 neck in recurrent laryngeal squamous cell carcinoma. Laryngoscope 2010;120:58-61.

11. Kürten CHL, Zioga E, Gauler T, Stuschke M, Guberina M, Ludwig JM, et al. Patterns of cervical lymph node metastasis in supraglottic laryngeal cancer and therapeutic implications of surgical staging of the neck. Eur Arch Otorhinolaryngol 2021.

12. Beck C, Mann W. The inner laryngeal lymphatics. A lymphangioscopical and electron microscopical study. Acta Otolaryngol 1980;89:265-70.

13. Werner JA, Dünne AA, Davis RK. Intraoperative lymphatic mapping in cases of midline squamous cell carcinoma. Acta Otolaryngol 2005;125:403-8. 
14. Myers EN, Fagan JF. Management of the neck in cancer of the larynx. Ann Otol Rhinol Laryngol 1999;108:828-32.

15. Marks JE, Devineni VR, Harvey J, Sessions DG. The risk of contralateral lymphatic metastases for cancers of the larynx and pharynx. Am J Otolaryngol 1992;13:34-9.

16. Güney E, Yigitbasi OG. Management of N0 neck in T1-T2 unilateral supraglottic cancer. Ann Otol Rhinol Laryngol 1999;108:998-1003.
17. Sarno A, Bocciolini C, Deganello A, Coscarelli S, Gallo O. Does unnecessary elective neck treatment affect the prognosis of N0 laryngeal cancer patients? Acta Otolaryngol 2004;124:980-5.

18. Weber PC, Johnson JT, Myers EN. The impact of bilateral neck dissection on pattern of recurrence and survival in supraglottic carcinoma. Arch Otolaryngol Head Neck Surg 1994;120:703-6. 